\title{
I Second That Emotion: Modelling the Anxious Experiences of
}

\section{Thirteenth-Century Bishops}

\author{
Philippa Byrne
}

\section{Searching for episcopal experience}

What did it feel like to be a medieval bishop? The question might strike one as trivial, even rather platitudinous. Modern writing on the lives of medieval bishops rightly begins by acknowledging the vast differences across the episcopacy: bishops were drawn from the ranks of royal administrators and servants; they might be selected as charismatic holy men; they numbered zealous reformers and learned theologians. ${ }^{1}$ This paper does not attempt to establish any singular model for understanding the medieval episcopacy. What it does argue, however, is that twelfth- and thirteenth-century writers constructed an emotional and rhetorical model for episcopal life, a model which all bishops could buy into. That model, emphasising the interior emotional endurance required by episcopal office, was valued as a tool for unifying a diverse range of figures, backgrounds and activities.

A medieval bishop was required to be many things to many people. In addition to longstanding ideas about virtuous behaviour and pastoral responsibilities, the later Middle Ages saw the proliferation of a bishop's administrative and legal duties. The period from c.1100 witnessed the beginnings of an 'episcopal bureaucracy', the establishment of diocesan registrars, and a greater demand for clerks to assist with ecclesiastical paperwork. ${ }^{2}$ Regardless of the status, size and wealth of the diocese, there were pastoral, administrative, legal and

\footnotetext{
${ }^{1}$ To pick one example among many, see Robert W. Dunning, 'Introduction' in Jocelin of Wells: Bishop, Builder, Courtier, ed. Robert W. Dunning (Woodbridge: Boydell Press, 2010), 1-8.

${ }^{2}$ See Michael Burger, Bishops, Clerks and Diocesan Government in Thirteenth Century England: Reward and Punishment (Cambridge: Cambridge University Press, 2012), esp. 7-8.
} 
political demands to be fulfilled, and it was the bishop who bore the ultimate responsibility for them.

We know this because bishops, their counsellors and assistants talked about those demands, ${ }^{3}$ developing an emotional language to describe their labours. Not only did this emotional frame help to explain what it was to be a bishop, it also assisted in distinguishing ecclesiastical lordship from secular lordship, just as bureaucracy and administration drew the two closer together in form. This article focuses not on accounts written by bishops themselves, but two letters written to bishops-elect, informing them about what to expect in their new office. The authors of these letters - the cleric and theologian Peter of Blois and the Franciscan friar Adam Marsh - had both observed the exercise of episcopal power close up. Their letters make it clear to their addressees that a bishop's lot is not a happy one - at least not in this life. Both articulate a set of ideas associated with labour, vigilance, care and anxiety. ${ }^{4}$ At the same time, neither Peter of Blois nor Adam Marsh were disinterested observers. Invoking the language of the emotional pressures on a bishop also served to empower the letter writers: they might volunteer their services as counsellors and promote their own theological agendas for how both bishop and Church might be shaped.

The two bishops addressed in these letter-treatises are John of Coutances, bishop of Worcester 1196-8, and Sewal de Bovill, archbishop of York 1256-7. ${ }^{5}$ Neither man has left much of a mark on posterity: both were in office for only a short time, and no personal writings survive beyond ordinary administrative documents. ${ }^{6}$ In short, for neither John nor

\footnotetext{
${ }^{3}$ For some sense of the multiple demands on a bishop's time, see A. Morey and C. N. L. Brooke, eds, The Letters and Charters of Gilbert Foliot (London: Cambridge University Press, 1967).

${ }^{4}$ For some reflections on the challenges in translating these terms from Latin, see William J. Bouwsma, 'Anxiety and the Formation of Early Modern Culture', in A Usable Past: Essays in European Cultural History, ed. William J. Bouwsma (Berkeley: University of California Press, 1990), 157-89.

${ }^{5}$ Sewal was in fact elected to York by the canons of the cathedral in 1255 on the death of the previous incumbent, but consecration was delayed until 1256, as Sewal required papal dispensation for his illegitimate birth, and thence royal assent to the election.

${ }^{6}$ For John, see Mary G. Cheney, ed., Worcester, 1186-1218, English Episcopal Acta 34 (Oxford: Oxford University Press, 2008); for Sewal, Charles Travis Clay, ed., York Minster Fasti, vol. 1 (Leeds: Yorkshire Archaeological Society, 1959).
} 
Sewal can we build up a very detailed picture. Yet this may be methodologically advantageous: these men were not saints, ${ }^{7}$ and though distinguished enough to advance to high office, they were, by the standards of episcopal careers, fairly ordinary.

Current studies of medieval bishops have relatively little to say about the emotional tribulations of episcopal office-holders. ${ }^{8}$ The most influential recent methodological approach to the medieval episcopate has emphasised the bishop's role as a courtier, and accordingly, the importance of the courtly quality of affability (affabilitas) in a bishop's life and behaviour. This is the argument advanced by C. Stephen Jaeger: from approximately 1000 onwards, what defined a medieval episcopal career was emotional self-regulation and an outward show of courteous behaviour, ${ }^{9}$ exhibiting the qualities of gentility, humility and emotional restraint (reflected in Latin descriptors like mansuetus, humilis and discretus). Jaeger's reading of episcopal office concentrates on episcopal vitae in which fitness for office was made evident through demonstration of 'gentle' behaviour. What was valued in a bishop was the kind of polite self-fashioning valued more widely in royal courts.

It is undeniable that bishops were courtiers, and that their office required them to move in courtly circles. ${ }^{10}$ As numerous thwarted careers demonstrated, episcopal ambitions rarely progressed far without tacit royal agreement, if not outright royal endorsement. ${ }^{11}$ But we can add a further dimension to this picture. Affability was not the sole register in which

\footnotetext{
${ }^{7}$ Though John was never a candidate for sainthood, by the early fourteenth century his body was reputed to be incorrupt, suggesting a holy life: see Diana Webb, Pilgrimage in Medieval England (London: Hambledon, 2000), 70.

${ }^{8}$ For possible reasons for this, see Anna Trumbore Jones and John Ott, 'Introduction: The Bishop Reformed', in Anna Trumbore Jones and John Ott, eds, The Bishop Reformed: Studies of Episcopal Power and Culture in the Central Middle Ages (Aldershot: Ashgate, 2007), 1-20.

${ }^{9}$ The 'origins of courtliness' thesis; see C. Stephen Jaeger, 'The Courtier Bishop in Vitae from the Tenth to the Twelfth Century', Speculum 58, no. 2 (1983): 291-325; expanded on in The Origins of Courtliness: Civilizing Trends and the Formation of Courtly Ideals, 939-1210 (Philadelphia: University of Pennsylvania Press, 1985). ${ }^{10}$ See Jaeger's own reflections: 'The Origins of Courtliness after 25 Years', Haskins Society Journal 21 (2009): 187-216.

${ }^{11}$ Cf. Everett U. Crosby, The King's Bishops: The Politics of Patronage in England and Normandy, 1066-1216 (New York: Palgrave Macmillan, 2013); for frustrated episcopal ambitions, see Gerald of Wales, De rebus a se gestis, ed. J. S. Brewer (London: Longman, 1861).
} 
bishops spoke. Indeed, it was not the language of affability that those in high ecclesiastical office used to communicate with one another. Rather, it was the emotional language of shared labour and pains - a rhetoric of toil, labouring and even of exhaustion. When trying to describe shared episcopal values and experiences it was pain and sorrow, not the dignity of office, which bishops and their reached for. As such, those holding high office in the medieval church fit the model elucidated by Barbara Rosenwein, whereby particular social groups, marked by particular sets of values, also exhibit particular modes of feeling and ways of expressing those feelings. ${ }^{12}$

In the episcopate, a language of shared sorrow and toil might be used to bridge significant gaps in space, time and place - something especially important in the generation of corporate sensibility. The examples I concentrate on here are two epistolary treatises written to English bishops. The English church in this period saw bishops drawn from a considerable diversity of backgrounds, ${ }^{13}$ yet they were obliged to communicate with each other, to address shared problems, to attend councils together. Communication began from the one thing they had in common: the demands of office, both spiritual and administrative, the particular kind of labour unique to those who wielded both temporal authority and spiritual burdens. This emotional language helped to glue together an episcopate, and, indeed, was intended to foster some sense of what an episcopate might be. ${ }^{14}$

\section{Precedents for exhaustion}

The ideas of episcopal office, and of Christian service were not, of course, invented in 1100. There were long-running and widespread precedents for conceiving of Christian life

\footnotetext{
${ }^{12}$ Most recently discussed in Barbara Rosenwein, Generations of Feeling: A History of Emotions, 600-1700 (Cambridge: Cambridge University Press, 2016).

${ }^{13}$ For a snapshot: David Knowles, The Episcopal Colleagues of Archbishop Thomas Becket (Cambridge: Cambridge University Press, 1951).

${ }^{14}$ Cf. John Sabapathy, Officers and Accountability in Medieval England, 1170-1300 (Oxford: Oxford University Press, 2014).
} 
and Christian struggle in a fallen world as a kind of service, labour or suffering. This view is evident in patristic thought as early as the fourth century and doubtless owed something to the memorialisation of earlier Roman persecutions and Christian martyrdom, ${ }^{15}$ but it was Gregory the Great's Regula pastoralis which proved most influential in forming medieval views of office-holding in the Church. The Regula pastoralis is well known as the foremost medieval guide to pastoral care; indeed, it was already a core text for Christian leaders by the eighth century, when Alcuin of York famously described as speculum pontificalis vitae containing all that a bishop would need to live a holy and exemplary life. ${ }^{16}$ Yet in this text there is relatively little discussion of a bishop's labours, or what it feels like to hold episcopal office. What Gregory provides is a laundry-list of qualities desirable in a bishop; all the things a pastor ought to be ${ }^{17}$ Gregory is primarily interested in describing what sort of virtues a pastor should display in order to rule. Visible in the Regula pastoralis, however, is a warning against relaxation of care: ${ }^{18}$ there are responsibilities which ought to occupy the pastor, and there are other jobs which threaten to fill up his time if he should let them. The watchword is solicitude (sollicitudo - a term we might also translate as 'anxiety'). ${ }^{19}$ This theme of care and solicitude which would come to be more fully developed, ultimately worked into an emotional vocabulary of office.

Beyond the Regula pastoralis, one of the most important passages for defining what a medieval bishop was derived from Paul's first letter to Timothy (1 Tim. 3.1): 'if a man desire the office of bishop, he desires good works (si quis episcopatum desiderat, bonum opus desiderat)'. Paul's letter then goes on to describe a set of qualities associated with episcopal office: sober, prudent, distinguished, chaste, hospitable, learned (sobrium, prudentem,

\footnotetext{
${ }^{15}$ Cf. Ambrose, De officiis, ed. Ivor J. Davidson, 2 vols (Oxford: Oxford University Press, 2001), XV.58, 152.

${ }^{16}$ Alcuini Epistoli, ed. E. Dummler, MGH Epistolae 4 (Berlin: apud Weidmannos, 1895), Ep. 116, 171.

${ }^{17}$ Regula pastoralis, ed. F. Rommel (Turnhout: Brepols, 2010), 2.1.

${ }^{18}$ Regula pastoralis, 2.7.

${ }^{19}$ Regula pastoralis, 2.1.
} 
ornatum, pudicum, hospitalem, doctorem). Early twelfth-century biblical commentary on 1 Timothy begins by providing the context for reading this letter. To take up the office of episcopatus is not a matter of increasing one's status, but of increasing one's labour: 'work, not rank; labour, not luxuries; not becoming greater by high office, but becoming smaller through humility, in order to become a servant and a minister to the people for Christ' ${ }^{20}$ While 1 Timothy was not exclusively applied to bishops, ${ }^{21}$ it was understood to speak to bishops above all. As a group, bishops' pastoral responsibilities which were the most onerous, for the simple reason that they were charged with the care of the greatest number of souls.

The connection between a bishop's duties, his inner self and his emotional endurance was elucidated with greater clarity in the later thirteenth century by Aquinas, in his lecturers on the Pauline epistles. Like his predecessors, Aquinas read 1 Timothy as a statement on episcopal governance. ${ }^{22}$ For Aquinas, it is only when the bishop himself has disposed and ordered the interior man properly than he is ready to lead others. He cannot rule unless his own spiritual life is ordered to the good. ${ }^{23} \mathrm{We}$ might also see this kind of concern reflected in one mid-thirteenth century hagiography: Matthew Paris' Vita sancti Edmundi, written c.1253, memorialising Edmund of Abingdon, the recently canonised Archbishop of Canterbury (d.1240). Matthew's Life develops, and greatly expands upon, an earlier life written by the monk Eustace. ${ }^{24}$ For Matthew, Edmund was an ideal archbishop - and one who 'detested

\footnotetext{
${ }^{20}$ Glossa ordinaria, PL. 114.628C.

${ }^{21}$ Cf. Roberti Grosseteste Epistolae, ed. H. R. Luard (London: Longman, 1861), Ep. 85 to the Augustinian canons of Missenden, Buckinghamshire, 268-70.

${ }^{22}$ Cf. Crosby, The King's Bishops, 9; for Aquinas, see Michael G. Sirilla, The Ideal Bishop: St Thomas Aquinas's Commentaries on the Pastoral Epistles (Washington, DC: Catholic University of America Press, 2017) esp. 104-9.

${ }^{23}$ Aquinas, Super Epistolas S. Pauli Lectura, ed. P. Raphael Cai, 2 vols. (Rome: Marietti, 1953), c. 3, lectio I, 2:231-33. See too Sirilla, The Ideal Bishop, 109.

${ }^{24}$ For the background and Latin text, C. H. Lawrence, Edmund of Abingdon, A Study in Hagiography and History (Oxford: Clarendon Press, 1960). An English translation (followed here) is provided in C. H. Lawrence, The Life of St Edmund (London: Sandpiper, 1999).
} 
sloth and idleness' (desidiam et ocia detestans). ${ }^{25}$ Edmund's model behaviour extended to regulating his activities and filling his days with profitable works: 'he was always occupied praying or meditating, correcting books, hearing confessions, resolving questions in the practice disputations of the friars, or giving judgment in legal disputes, lest the enemy of the human race should find him idle or resting from good works' ${ }^{26}$ It would be a mistake to read Edmund's dislike of idleness merely as the kind of virtuous opposition to sloth (acedia) expected of every Christian. Matthew Paris is describing a particular kind of labour associated with office-holding, as is made clear when the text offers us a glimpse of Edmund's schedule. Edmund never allowed his elevation to high office to curtail his customary devotion to prayer and personal devotions. He simply changed the hours of his prayer, attending to them at night when all others were asleep - a model of diurnal administration and nocturnal prayer. Indeed, when in Rome, Edmund was summoned by the Pope Gregory IX in the dead of night, only for the Pope to be impressed and full of admiration at the fact that despite the demands of his office, Edmund was able to keep up his spiritual devotions. This is no miracle, but is presented as an impressive demonstration of Edmund's personal sanctity. Indeed, Matthew has Edmund wish that he was no archbishop but instead a simple monk, rid of all the troubles (sollicitudines) accompanying high office, and able to live a good and peaceful life without attending to any administrative duties. In fact, the two terms which define Matthew's vision of Edmund, the devoted and sleepless archbishop, are occupatio and sollicitudo.

In the period from c.1100, a connection between office and emotional labour and internal preparation was being articulated more explicitly than it had ever been before. The additional administrative burdens placed on the bishop, burdens which threaten his soul, must

\footnotetext{
${ }^{25}$ Life, c.XXI, 243.

${ }^{26}$ Life, c.XXI, 243. In these descriptions of episcopal labours, Matthew is adding to, not repeating, his source material.
} 
be mitigated in two ways: the first, by increased attention to the 'interior' man to prevent loss of virtue; the second by emotional endurance of the labours which administration must inevitably bring.

Where that connection between labour in office and emotional response is most evident is in Bernard of Clairvaux's De consideratione. This text provides an extremely detailed picture of the personal burdens of office, and the anxiety associated with a pastor determining whether he performs his labours adequately. De consideratione, which Bernard worked at from 1148 to 1153 , was addressed to Pope Eugenius III, a former monk of Clairvaux. ${ }^{27}$ That connection provided Bernard with the authority to counsel the man who now held the highest office in Christendom; writing as a concerned spiritual father to one who had once been under his authority. Bernard laments that the responsibilities of papal office, and, in particular, the ever-expanding business of the law courts threaten not just to occupy Eugenius' time, but to consume all of his intellectual attention and dominate what we might term his emotional life. The text is, part, this is a token of the changed and stillchanging role(s) of the papacy in the mid-twelfth century; its 'capture by lawyers', the slow crystallisation of its formal role at the legal (as well as spiritual) centre of Christendom. ${ }^{28}$ What is most striking is the emotional equation Bernard makes in De consideratione. This is structured around several premises. First, that a bishop's life can never be a quiet one: a life of pure contemplation and singular dedication to personal spiritual improvement must be set aside when one takes up office. Secondly, that this promotion to high office becomes an occasion for sorrow, because of its loss of quiet. Thirdly, that Eugenius' is filled with danger:

\footnotetext{
${ }^{27}$ For the intellectual background, see E. Kennan, 'The De Consideratione of Bernard of Clairvaux and the Papacy in the Mid-Twelfth Century: A Review of the Scholarship', Traditio 23 (1967): 73-115.

${ }^{28}$ Cf. Guilio Silano, 'Of Sleep and Sleeplessness: The Papacy and Law, 1150-1300', in The Religious Roles of the Papacy: Ideals and Realities, 1150-1300, ed. Christopher Ryan (Toronto: Pontifical Institute of Medieval Studies, 1989), 343-61.
} 
that one becomes so accustomed to administrative burdens, so habituated to bureaucratic work, that one loses any time for true spiritual labours. ${ }^{29}$

Bernard writes from a monastic tradition: any administrative work must provoke feelings of sorrow in Eugenius - sorrow over lost time, time which might have been spent in spiritual progress. ${ }^{30}$ If Eugenius cannot prevent these administrative, non-spiritual matters being brought to him, his sorrow must form a defence: sorrow over 'wasted' time is useful to him, because it will remind the pope of where his real priorities ought to lie. Sorrow is necessary in the life of an ecclesiastical office-holder, a reminder of the dangers of his office: and the greater the office, the greater the threat, the more riddled with danger the labour. Bernard plays with the vocabulary of consolation, setting up the ostensible purpose of the letter as commiseration on office. Yet, at the same time, Bernard constructs this loss of freedom and loss of quiet as a noble sacrifice: the pope is yoked into service: 'though I were free from all, I made myself the servant of all' ${ }^{31}$ We should read the title Bernard chose for his treatise - De consideratione - as making a statement about the proper regulation and balance of an ecclesiastical office-holder's emotional life. For it is consideratio which preserves the pope: consideratio is the virtue which maintains a balance between the necessary bureaucratic and administrative work of high office and the 'pleasures' of spiritual labour. $^{32}$

\section{Peter and Adam}

\footnotetext{
${ }^{29}$ De consideratione, in S. Bernardi Opera, vol. 3, ed. Jean Leclercq, Henri Rochais and Charles H. Talbot (Rome: Editiones Cistercienses, 1963), 1.2, 395.

${ }^{30}$ De consideratione, 1.2, 395.

${ }^{31}$ De consideratione, $1.4,398$, citing 1 Corinthians 9.19

${ }^{32} \mathrm{Cf}$. De consideratione, 1.8, 404, for consideratio as a kind of umpire, and its relation to temperance.
} 
De consideratione was a popular text, both in the twelfth century and for some several centuries afterwards. ${ }^{33}$ What has sometimes been missed are the texts it inspired: texts which grapple with the themes about the emotional endurance required of those in the ecclesiastical hierarchy. It is here I turn to Peter of Blois' epistolary treatise, De institutione episcopi ('On Episcopal Office') - sometimes also known as Canon episcopalis - a letter addressed to John of Coutances, the newly-elected bishop of Worcester. Peter himself had experience in episcopal service, having spent many years working for Richard of Dover, archbishop of Canterbury 1173-83; and as archdeacon of Bath had a close view of the church, its hierarchy and its demands. Yet John was not obviously in need of such advice from Peter: he had considerable experience of church administration as archdeacon of Oxford and dean of Lisieux. Moreover, had John required assistance in understanding the inner workings of episcopal office, he could look for it close to home: his uncle, Walter of Coutances, was the former bishop of Lincoln and the current archbishop of Rouen. ${ }^{34}$

As with Peter's other letters, this piece was not intended for John alone, but to be circulated more broadly; as a treatise to be read, where its erudition might be admired and from might numerous, nameless others might perhaps draw instruction. This, in part, explains why so little (almost nothing) is said about Worcester, and why Peter speaks to a more general conception of episcopal office. Peter asserts that a bishop's behaviour is a matter of public concern, for to be a bishop is to govern (superintendere) the people. In part, this is what gives Peter licence to opine on the subject. Peter is also modelling himself after Bernard

\footnotetext{
${ }^{33}$ For one context in which the text was read, see Walter Ullmann, The Growth of Papal Government in the Middle Ages (London: Meuthen, 1955), 426-36. Bernard had also addressed a letter on office to an archbishop Henry of Sens - but this proved less influential than De consideratione, and the letter devotes considerably more time to virtue than episcopal administration. Ep. 42 in S. Bernardi Opera, vol. 7, 100-31.

${ }^{34}$ Indeed, Peter advises John to imitate the virtues of his uncle, De institutione episcopi, PL.207.1099C.
} 
it seems likely that he had De consideratione in mind when composing this letter, and modelled his own writing after Bernard's influential performance. ${ }^{35}$

Peter positions himself as preparing John emotionally for the experience of office, for the burdens he is about to take on and which he will not be able to put down. ${ }^{36}$ The first question Peter addresses is how a bishop can be sure that he is fulfilling his responsibilities. The short answer is, if he is busy, if he is pressed, then this is at least the initial sign that a bishop has approached his role correctly. It is, however, more complicated than this: there is much in this life which can disturb you, Peter advises; and the trick is that a bishop should only be 'disturbed' by the right things, by things of real spiritual import, and not by the concerns of the secular world.

What John of Coutances must also know, Peter advises, is that being a bishop is a job for both the day and the night. By day, he must perform the functions of his office, but he must also set aside time (typically, the night) to fulfil the needs of his spiritual life. The distinction here is not between public and private realms but rather between exterior and interior man. Peter here seems to be moving towards the conception that Aquinas will more fully articulate in his commentary on 1 Timothy: that an episcopal role is almost a dual one; a bishop cannot lead unless he has made and continues to make his own spiritual progress. It is not so much a question of giving up the spiritual life, as adding an additional administrative burden to it. But to achieve such a balance will requires self-assessment and scrupulous accounting. Every day, Peter instructs, the bishop must render an account in his conscience as to whether he has completed his works. ${ }^{37}$ He must measure whether he has slept too much, read too little or prayed too little. If office has led him to neglect his interior life, sorrow will ensue. The implication inherent in Peter's letter is that there is an internal process of self-

\footnotetext{
35 John D. Cotts, 'Monks and Mediocrities in the Shadow of Thomas Becket: Peter of Blois on Episcopal Duty', Haskins Society Journal 10 (2001): 145-64, esp. 155.

${ }^{36}$ De institutione episcopi, PL.207.1097-1112, 1099B.

${ }^{37}$ De institutione episcopi, PL.207.1101D; cf. 1106B-C, 'otiositas inimica est animi'.
} 
regulation which every bishop must undertake in order to make himself fit for his office: daily considerations of what he has accomplished, and whether he has fulfilled spiritual virtues.

It is this emotional response to the burdens of power, however, which marks the difference between the lordship as exercised by a secular ruler and the ministry exercised by a bishop. A bishop wields his authority under sufferance, and does not relish it. This marks a stark contrast with royal power: 'kings rule over their people (reges gentium dominantur eorum)', Peter explains, 'but you should not exhibit domination but ministry'. A minister does not enjoy his power, but suffers through it, ${ }^{38}$ and thus ministerium 'brings more burden than honour'. ${ }^{39}$ Peter was asserting this distinction at just the time when theologians were exercising themselves to explain what the difference between royal and ecclesiastical power might be. ${ }^{40}$ Here Peter roots that distinction in approach and feeling: even when doing 'administrative' work, the bishop approaches it differently to a secular administer - he does it as part of his duty, rather than for reward or the status which comes with it. We might read this as a response to twelfth-century changes within the church. As the church was coming to appear more institutional, more 'bureaucratic', the way in which to differentiate it further from the secular bureaucracy, to emphasise its spiritual status, was to focus on the emotional response and interior lives of those in ecclesiastical office.

Peter reaches for two scriptural analogies to illustrate the role of labour in a bishop's life. The first is that of Joseph in Egypt (as described in Genesis 46). ${ }^{41}$ There in Egypt, Joseph, a prisoner, fulfilled every role assigned to him. Though led into an unfamiliar land and life of toil, he thought no task beneath him and applied himself to the role. The second

\footnotetext{
${ }^{38}$ De institutione episcopi, PL.207.1103D.

${ }^{39}$ De institutione episcopi, PL.207.1107B.

${ }^{40} \mathrm{Cf}$. Philippe Buc, 'Principes gentium dominantur eorum: Princely Power Between Legitimacy and Illegitimacy in Twelfth-Century Exegesis', in Cultures of Power: Lordship, Status and Process in TwelfthCentury Europe, ed. Thomas N. Bisson (Philadelphia: University of Pennsylvania Press, 1995), 310-28.

${ }^{41}$ De institutione episcopi, PL.207.1105A.
} 
analogy is one of farming: Peter exhorts the bishop to see himself in the role of villicus - a steward, or estate manager. Long hours and tiresome toil is the analogy which best describes life in high ecclesiastical office. ${ }^{42}$ The other important and associated idea is that there is nothing attractive about this role. It is low labour, 'agricultura Dei' ${ }^{43}$ Service is a burden as painful and as backbreaking as labouring in the fields, not a matter of dignity or power. A pastor of the church is more like a farmer than a steward than he is like a prince or baron: his staff of office is not to be likened to a sceptre, but a hoe (sarculum) ${ }^{44}$

Throughout this experience of episcopal office, Peter writes, counsel will be critical: there will be so many critical and difficult issues to deal with that John will not alone be able to make sense of them. The most difficult decisions must be carefully weighed, with counsel and in full, the bishop first seeking for an answer in himself - but then turning to others for advice, most especially his household and his collaterales ('associates'). ${ }^{45}$ Peter offers himself as someone who can assist John in shaping his episcopate; turning the letter towards himself. The only way that a bishop will succeed in his service is through support, through the sharing of burdens with those who understand how hard the labour can be.

Almost half a century after Peter wrote to John of Coutances, another new bishop received an epistolary treatise warning about the burdens of the office he was about to take up. This is Adam Marsh's Letter 245, written to Sewal de Bovill, written relatively soon after Sewal's consecration at York, although before he took up office. ${ }^{46}$ Adam, like Peter, positioned himself as a counsellor and spiritual advisor to the great and the good of

\footnotetext{
42 The same analogy is also used by Bernard of Clairvaux in De consideratione 2.6. The figure of the 'steward' could be used in another way, to discuss virtue and Christian debts to God, e.g. as used by Odo of Tournai (d.1113) in his Homilia de villico iniquitatis, PL. 160.1121-50.

${ }^{43}$ De institutione episcopi, PL.207.1105B.

${ }^{44}$ De institutione episcopi, PL.207.1105A-B.

${ }^{45}$ De institutione episcopi, PL.207.1101B.

${ }^{46}$ Adam's significance for the history of the Franciscan order in England and his letter collection is discussed more generally in Amanda Power, 'The Friars in Secular and Ecclesiastical Governance', in The English Province of the Franciscans (1224-c.1350), ed. M. Robson (Leiden: Brill, 2017), 28-45, esp. 42-3. It is possible Adam was familiar with Peter's letters - the collection circulated widely - but there is no evidence for this.
} 
thirteenth-century England - a category which included Henry III; his wife Eleanor, Simon de Montfort, and - naturally - the leaders of the Franciscan order. We should note, however, that it was unusual for Adam to write to a bishop: other than Robert Grosseteste, bishop of Lincoln and Adam's closest friend, he addresses no other letters to bishops, though he writes to papal nuncios and members of the Franciscan hierarchy. These other letters, however, unlike Letter 245, are largely brief and business-like. This in itself may add support to the argument that Adam was consciously modelling this letter as a treatise set apart, modelled on Bernard's De consideratione.

Before his election, Sewal de Bovill had served as both archdeacon of York and dean of York (making for a background not dissimilar to that of John of Coutances); he was a doctor of theology and Chancellor of Oxford University. Again, like John of Coutances, Sewal must have had considerable knowledge of the see to which he was now appointed. Adam was a successful counsellor, an accomplished theologian, and in demand for his spiritual advice. Yet according to the letter, what really makes him qualified to talk about episcopal life and behaviour is his long and close association with Robert Grosseteste, whom Adam believed to have been a saint. ${ }^{47}$ It is this connection Adam plays on in the letter, stating that Grosseteste had always had a special affection for Sewal; and that Grosseteste now holds a crown in heaven because of how he exercised himself on earth. ${ }^{48}$ It is not surprising that we should find Adam inviting members of the English episcopate to imitate Grosseteste. What we should note, however, is that 'imitation' in Adam's construction is primarily matter of emotional orientation and attitude. What is to be emulated is Grosseteste's extraordinary vigour; a man who while he lived was ever 'toiling... with his salutary watchfulness (salutari vigilantia laborans) ${ }^{4}{ }^{49}$

\footnotetext{
${ }^{47}$ On Grosseteste's sanctity, see Eric Kemp, 'The Attempted Canonisation of Robert Grosseteste', in Robert Grosseteste, Scholar and Bishop, ed. Daniel A. Callus (Oxford: Clarendon Press, 1955), 241-6.

${ }^{48}$ The Letters of Adam Marsh, trans. C. H. Lawrence, 2 vols (Oxford: Clarendon Press, 2006-10), 2:613.

${ }^{49}$ Adam, Letters, 2:643.
} 
Adam begins in a traditional key for addressing a new overseer in the church, with his own version of the list of pastoral qualities and responsibilities found in Gregory the Great. An archbishop must accomplish certain duties, according to the different groups he serves: to the prince, he must show fealty, for the bishops, he must provide protection; he must support the clergy in learning and understanding; provide discipline for the religiously professed; he must guide nobles; must teach knights how to moderate themselves; to the people (ad plebes) he must give gentle guidance. ${ }^{50}$ This makes for a rather standard narrative, elucidating the weighty responsibilities which Sewal must now bear. Just as Peter of Blois, Adam presents the 'dual' responsibilities of office: he must balance his requirement to care for the people with attending to his own spiritual growth; for one cannot be achieved without the other. The analogy Adam employs to illuminate this is that of Moses ascending Mount Sinai to speak to the Lord: the pastor must repeatedly ascend and descend the mountain; he must climb up to spiritual things in order to speak to God, then descend to the earth in order to minster to his people. $^{51}$

Adam gives specific instruction as to the qualities one might look for in a pastor and why each of them is necessary and desirable. But he is also building up a description of what it feels like to hold episcopal office, and the need to meet these pressing demands - pressing because in some way they all tend to the matter of salvation. To serve in the church is to be a labourer in the work of salvation, but a lonely labourer and one who will always feel overburdened, for 'the harvest indeed is great, but the labourers are few. ${ }^{, 52}$

The significance of labouring is also emphasised by what Adam identifies as the greatest sin that can be demonstrated in episcopal office: omission, lack of action and lack of vigilance. Sloth in office is almost the dangerous as lack of belief; because sloth means that

\footnotetext{
50 Adam, Letters, 2:579.

51 Adam, Letters, 2:581.

${ }^{52}$ Adam, Letters, 2:587, echoing Matthew 9.
} 
the work of salvation will go uncompleted. ${ }^{53}$ Hence, when the time comes for God to judge all, what he will condemn are 'not the faults committed by prelates, but their omissions' (non comissa sed omissa prelatorum).$^{54}$ In this sense, the opposite of negligent omission is to endure patiently (agonias tolerare longanimiter) ${ }^{55}$ one way in which the bishop's role can be characterised.

Adam takes a further step, and sets out a programme for how Sewal should deal with the responsibilities placed upon him. It goes much further than Peter of Blois's advice to seek out counsel. Because these duties are so onerous, and so challenging for one man to take upon him, that an archbishop must seek assistance: 'it is most clearly apparent that there is need to call to his help a company of effective assistants, learned counsellors, caring ministers, and practised governors, who are therefore tried in the exercise of power, of shining truthfulness, of fervent holiness, and steadfast in their constancy' ${ }^{56}$ Even the appointment of subordinates, however, will be a tiring process and one which demands vigilance. ${ }^{57}$ Adam use the language of exhaustion, tiredness and (arch-)episcopal anxiety to make the case for Sewal looking to the mendicant orders for support in office. To make that connection here, Adam returns to the figure of Moses, citing Moses speech to the Israelites in which he explained that as their population had grown so large, he alone could no longer support the burden of ruling over them all directly (as described in Deuteronomy 1). As such, Moses appointed subordinates, the wisest men from each tribe. This, Adam explains, is a model for the church: duties must be apportioned accordingly.

From Adam's (long) letter, a nexus of ideas emergences. First, the prelate must always be labouring, and struggling (this is the bread and butter of church office). He must be

\footnotetext{
53 Adam, Letters, 2:589.

${ }^{54}$ Adam, Letters, 2:609.

55 Adam, Letters, 2:611.

56 Adam, Letters, 2:579.

57 Adam, Letters, 2:581.
} 
vigilant in the sense of ensuring he undertakes all the work that is committed to him. He must be patient and constant; he must prepare himself, and expect to endure hardships. The archepiscopal role is not described in terms of its dignity, but figured as hardship (dura) to be endured with long-suffering patience. ${ }^{58}$ The best that a bishop or archbishop can hope for is that his time in office be a struggle, but a triumphant struggle - following the experiences of men who were tested were found to be ready for that test; men like the virtuous patriarchs of the Old Testament; Abraham, Isaac, Jacob and Moses. ${ }^{59}$ The paradox here is that this hard work - this action of being tested, tried, and tired - may actually produce feelings of happiness and hope in the bishop when he considers the special glory that awaits him as recompense for these labours: 'although tribulations and vexations disturb us and make us sad, yet they give us joy' ${ }^{60}$ Later in the treatise, Adam avers that 'it is a wonderful thing (stupendus est)' to be obliged to work so hard and so long on behalf of the Church. ${ }^{61}$

It is worth underlining the significance of the semantic field running throughout Adam's letter treatise, for it is informed the same ideas and terminology which Bernard of Clairvaux had employed over a century before - a text which Adam occasionally cites. ${ }^{62}$ There can be no pleasure in office, and, indeed, office-holding requires the bishop to let go of any of the pleasures of the present life in order to serve (abdictationem presentis vite iocunditatem). ${ }^{63} \mathrm{He}$ who serves in office finds himself 'in want, distressed and afflicted' (egentes, angustiati et afflicti, a paraphrase of Hebrews 11.36-8). Most importantly of all, however, Adam repeatedly reaches for two key terms: solicitude (sollictudo) ${ }^{64}$ and

\footnotetext{
58 Adam, Letters, 2:645.

${ }^{59}$ Adam, Letters, 2:631-3.

${ }^{60}$ Adam, Letters, 2:629.

${ }^{61}$ Adam, Letters, 2:645.

62 e.g. Adam, Letters, 2:635.

${ }^{63}$ Adam, Letters, 2:585.

${ }^{64}$ e.g. Adam, Letters, 2:632, 2:640, 2:644; it is also used in other letters to describe high office, e.g. Ep. 199, $2: 488$, speaking of 'tireless vigilance' (sollicitudinis vigilantia). 'Solicitude' is also used several times by Peter of Blois, e.g. 207.1105B, 1107.
} 
vigilance/watchfulness (vigilantia and its cognates). ${ }^{65}$ Taken together, what all these terms make clear is that Adam is not simply describing a generalised Christian experience of tribulation in a fallen world and the need to persevere: he is tapping into a very specific vocabulary in order to describe the emotional and interior experience of office-holding in the medieval church.

It would not do to minimise entirely the differences between Peter of Blois and Marsh's treatises. In addition to the recommendation of specifically mendicant support for Sewal, Adam's letter is engaged with the problems of the English church under Henry III; the depredations it has suffered and the need for Sewal to be robust in office - and he goes as far as setting out a four-step plan for Sewal to implement, itemising specific policies. ${ }^{66}$ Yet what is striking are the continuities between the two: Adam, a Franciscan friar, does not try to mould Sewal into a 'Franciscan' bishop; like Peter he sounds the same note (an old idea) of preparing oneself for toil and for service. For Adam, the difference between admirable pastors and wicked ones is not defined by any particular action or policy, but by the presence or absence of care, perseverance and vigilance. ${ }^{67}$ Those bishops who fail in the episcopal office are like those who purchase the tools for cultivation but then fail to set to work in the vineyard. ${ }^{68}$

Indeed, in writing to Sewal, Adam was following the practice of his mentor, Grosseteste, who had himself written a letter to the new archbishop of Canterbury. In 1243/4, Grosseteste had addressed Boniface of Savoy, adopting a now familiar theme: the immensity and seriousness of the task facing him. ${ }^{69}$ In $1243 / 4$, that burden truly was great: the previous incumbent, Edmund, had died in November 1240, and Canterbury remained without a

\footnotetext{
65 e.g. Adam, Letters, 2:641, 2:643.

${ }^{66}$ Adam, Letters, 2:641.

67 Adam, Letters, 2:627.

68 Adam, Letters, 2:627.

${ }^{69}$ Grosseteste, Ep. 86, 271-2.
} 
consecrated archbishop. When Boniface finally came into his post, the job would be do undo the considerable damage that had accrued to the church in that time: 'strengthening the weak, healing the sick, binding up the injured' ${ }^{70}$ What awaited Boniface was 'watchful concern and tireless labour' (sollicitudine indefessoque labore). But Grosseteste does not merely write to urge Boniface to apply himself; he writes with something else in mind - an offer to support, to make himself available, to share in the burden of it; setting himself as one of Boniface's 'obedient and painstaking fellow-workers' (obedientes et sedulos cooperatores). ${ }^{71}$ The value of the emotional language of labour for building connections across the episcopate is here evident.

\section{Labour and pain: a common language}

It is tempting here to draw a parallel between thirteenth-century visions of episcopal labour and modern discourses of status and exhaustion. The early decades of the twenty-first century have seen the rise of a competitive working culture (not least in academia), where devotion to work and overtime can be seen as a badge of pride, even a demonstration of status. ${ }^{72}$ The elite are not a leisure class but an over-working class: we are bombarded with information about how early the most successful CEOs rise in the morning, how much they have accomplished even before breakfast. That reality, is, unsurprisingly, reflected in an anxious and vigilant language: of productivity enhancements, of work-life balance and lifehacks, of 'brain-boosting hobbies' and emulating the habits of highly effective people. ${ }^{73}$

Episcopal office was an 'anxious' experience. It required intensive self-scrutiny; every action was to be weighed in order to assess whether one had profitably used one's time.

\footnotetext{
${ }^{70}$ Grosseteste, Ep. 86, 271, paraphrasing Ezekiel 34.4.

${ }^{71}$ Grosseteste, Ep. 86, 271.

${ }^{72}$ Cf. S. A. Hewlett and C. B. Luce, 'Extreme Jobs: The Dangerous Allure of the 70-hour Workweek', Harvard Business Review 84, no. 12 (2006): 49-59.

${ }^{73}$ For a particularly egregious example of the genre, see I. Trump, Women Who Work: Rewriting the Rules for Success (Portfolio/Penguin: New York, 2017).
} 
As bishops' lives were often the subject of critical commentary by medieval chroniclers, to see this 'internal audit' is not entirely surprising. A bishop was not expected to become habituated to the challenges of his office. He could adapt his routine, but he was not permitted to relax into it. Solicitude (sollicitudo), as term which features prominently in the texts examined here, means to be wracked daily with concerns. Pastoral care meant disturbance. ${ }^{74}$ A special category of worry and pain attached to the exercise of ecclesiastical lordship and oversight. If we miss it, we overlook one of the fundamental aspects of ecclesiastical office. We might think of Innocent III's description of lordship, a role in which one must always be vigilant of the dangers assailing the faithful, and a job which requires not just diurnal solicitude, but nocturnal vigilance: 'Nor is the evil sufficient unto the day, but day brings out the labour of the day and night exposes the anxiety of the night. Thus days are full of the pains of labour, and the nights are endured without sleep' ${ }^{75}$ Innocent III was, of course, writing here in a particular context and genre - de contemptu mundi - on the dangers of the world, warning how easily humans might be corrupted by it. The point, however, was to feel this burden, in order to maintain one's spiritual alignment. As Bernard emphasised, sorrow was necessary - for it would remind Eugenius to keep to the straight and narrow.

The focus throughout this article has been on the responsibilities of bishops; but we might wish to cast that net more widely and think of this as a rhetoric which could be shared with anyone holding high office in the Church - which might too extend to archdeacons and abbots, although the problem was felt and expressed more acutely the further one advanced in office. The language of burden and labour could be used to connect bishops to the patriarchs of the Old Testament; it also provided a useful counterweight to accusations that a particular

\footnotetext{
${ }^{74}$ De institutione episcopi, PL.207.1105B.

${ }^{75}$ De miseria condicionis humanae, ed. M. Maccarrone (Lugano: Thesauri Mundi, 1955), 22. 'Nec sufficit diei malitia sua, sed dies dici laborem eructat et nox noctis sollicitudinem indicat. Dies ergo laboriosi ducuntur et noctes expediuntur insompnus'.
} 
bishop was puffed up by pride, arrogance at his status and wealth. ${ }^{76}$ It had a further, pragmatic use for those counselling bishops - Adam Marsh uses the prospect of episcopal exhaustion to urge Sewal to seek out mendicant support, to make full use of the friars so as to manage the labour required. ${ }^{77}$ Adam's mentor (and the exemplar of episcopal life he sets out for Sewal), Robert Grosseteste, had done much the same, deploying a language of pastoral exhaustion in a careful and strategic way. Grosseteste uses the great emotional burdens of pastoral office to refuse to appoint those whom he does not think are sufficiently committed to the office. Given Grosseteste's fervent commitment to pastoral reform, we need not interpret these refusals as mere excuses; but certainly they allow him to give a good reason for refusing those whom he regards as unsuitable candidates. It is not merely, Grosseteste explains, that your candidate is not sufficiently well trained: it is also the fact that your candidate will not be able to bear the emotional labour it requires of him. It is as dangerous for the pastor as the parish. Refusing to institute a colleague's nephew to a church living, Grosseteste explained that the central feature of pastoral office was 'to endure gladly all hardships, even the most distressing and perplexing, ${ }^{78}$ Because this nephew demonstrated insufficient abilities to endure, Grosseteste could not agree to the appointment. Grosseteste adopted the same tactic when refusing to appoint the son of the Earl of Derby to a benefice in the diocese of Lincoln in 1238, arguing that pastoral care was a burden which could only be placed on the strong, and comparing the candidate to a calf who would sink down under the heavy weight of a plough. ${ }^{79}$

\footnotetext{
${ }^{76}$ See, for example, William of Malmesbury's verdict on the wealthy Roger of Salisbury, Gesta Regum Anglorum, trans. R. A. B. Mynors, 2 vols. (Oxford: Clarendon Press, 1998-9), 2:483-4.

${ }^{77}$ On this point see c. 10 of the Fourth Lateran Council in Norman P. Tanner, Decrees of the Ecumenical Councils, vol. 1 (London: Sheed and Ward, 1990), 239-40; William A. Hinnebusch, The Early English Friars Preachers (Rome: Ad S. Sabinae, 1951), 442-57. For Grosseteste's requests for assistance from the mendicant orders: Ep. 14, 59-60; Ep. 15, 61; Ep. 16, 62-3.

${ }^{78}$ Ep. 72, to the subdean of York, John le Romeyn, 203, 'omnia etia molestissima et confusibilia gaudenter sustinere'.

${ }^{79}$ Ep. 52, 152.
} 
We might be tempted to dismiss this merely as a useful rhetoric; to suggest this language was a convenient shield for bishops whose lifestyles sometimes diverged far from the apostolic ideal. Perhaps John of Coutances' hours were not as long as Peter of Blois would have us believe. Certainly, bishops could make the time to hunt, to attend court, to be affable. That does not mean, however, we should consider this as pure posturing; if it was a useful language, it was in some quarters taken very seriously indeed. Grosseteste may be an extreme example in terms of personal action - one who took his cura so seriously that he resigned an archdeaconry when he did not believe he could properly fulfil the other demands on his time $e^{80}$ - but he was not an outlier in terms of his broader understanding of office and ministry. Grosseteste articulated a common view in the medieval church when he wrote that the dangers of high office were 'neither few nor small', ${ }^{81}$ and when he described the pastor's role as a burden 'heavy and filled with terrors' ${ }^{82}$

The final suggestion I should like to make turns on the possibilities inherent in this rhetoric for how we think not just about office holding, but also networks and sociability. When medievalists examine letter collections, we often focus on the language of 'friendship' (amicitia) as a key principle; a language which adapted classical and Ciceronian ideas about friendship and allowed the generation of epistolary networks. An exchange of letters kept up friendships between distant monasteries, the conventions of friendship were an important feature in writing and exchanges, generating an epistolary network which spanned across Europe, which followed churchmen across appointments and throughout their lives. ${ }^{83}$ Even if that language was confected, this rhetoric - adopting this scheme of friendship - made

\footnotetext{
${ }^{80}$ Ep. 9, 45-7 - a letter written to Adam Marsh.

${ }^{81}$ Ep. 9, 'non pauca vel parva'.

${ }^{82}$ Ep. 13, 57-9, 'onerosum est et terroribus plenam'.

83 e.g., Julian Haseldine, 'Understanding the Language of Amicitia: The Friendship Circle of Peter of Celle (c.1115-1183)', Journal of Medieval History 20 (1994): 237-60, and Haseldine, 'Friendship Networks in Medieval Europe: New Models of a Political Relationship', AMITY: The Journal of Friendship Studies 1, no. 1 (2013): 69-88.
} 
communication easy, greased wheels, provided a means by which counsel might be shared on an equal footing. Yet just as strong a bond might be created through shared complaint. Cura, after all, bore the dual meaning of both anxiety and administration. Complaint could be as cohesive as supportive epistles of friendship - indeed, the two could work in tandem. Shared friendship was also shared sorrow for the hardness of office and its pains, but affirming those emotional and spiritual pains were valuable: the pain meant it was going according to plan.

St John's College, University of Oxford philippa.byrne@history.ox.ac.uk 